Article

\title{
Preparation of Hierarchical Porous Carbon Aerogels by Microwave Assisted Sol-Gel Process for Supercapacitors
}

\author{
Xueqing Cai, Guiming Tan, Zhentao Deng, Jianhong Liu and Dayong Gui *
}

College of Chemistry and Environmental Engineering, Shenzhen University, Shenzhen 518055, China; xueqing_cai1026@163.com (X.C.); tanguiming530@126.com (G.T.); 18316787927@163.com (Z.D.); liujh@szu.edu.cn (J.L.)

* Correspondence: dygui@szu.edu.cn

Received: 27 January 2019; Accepted: 28 February 2019; Published: 6 March 2019

\begin{abstract}
Low-cost resorcinol formaldehyde (RF) organic aerogels were prepared by using resorcinol and formaldehyde as precursors, and sodium hydroxide as a catalyst through a single-mode microwave radiation-assisted sol-gel method and ambient temperature drying. Because of the ring focusing and power-max technology, the fabrication procedure of carbon aerogels (CAs) are much easier, faster, and cheaper than traditional methods. The RF aerogels were then pyrolysized at $900{ }^{\circ} \mathrm{C}$, and the $\mathrm{KOH}$ activation process was used to further dredge micropores in the carbon aerogels. The CAs were characterized by X-ray diffraction (XRD), scanning electron microscopy (SEM), nitrogen adsorption/desorption, and a series of electrochemical tests. The $\mathrm{KOH}$ activated carbon aerogels with 3D-nano-network structure exhibited a high specific surface area of $2230 \mathrm{~m}^{2} \mathrm{~g}^{-1}$ with appropriate pore volumes of micro-, meso-, and macropores. The specific capacitance of CAs activated by $\mathrm{KOH}$ measured in a two-electrode cell was $170 \mathrm{~F} \mathrm{~g}^{-1}$ at $0.5 \mathrm{~A} \mathrm{~g}^{-1}$ with excellent rate capability and cycle stability in $6 \mathrm{M} \mathrm{KOH}$ electrolyte.
\end{abstract}

Keywords: microwave; carbon aerogels; hierarchical porous; $\mathrm{KOH}$ activation; supercapacitor

\section{Introduction}

Supercapacitors, a unique class of electrical energy storage devices, have attracted tremendous attention in recent years owing to their capability of delivering high power density and remarkable cycling stability [1-4]. Various materials have been chosen to fabricate electrodes of supercapacitors, such as conducting polymers, metallic oxides, and carbon-based electrode, each of them has both advantages and drawbacks [5-7]. Porous carbon nanomaterials, with a hierarchical channel of pores, high surface area, and stable mechanical properties, are attracting increasing interest due to their potential applications in hydrogen storage and electrochemical capacitors [8-12].

Carbon aerogels, as one of the 3D porous carbon-based materials, has attracted widespread interest because of their unique three-dimensional nano-network, high conductivity, and the possibility of tailoring their structures to produce final materials that fit the requirements of a specific application $[13,14]$. Hence, it has been used in various fields, such as catalysis, adsorption, and energy storage [15]. The preparation of CA mainly includes three steps: gelation and curing reactions, drying treatment, and the pyrolysis process [16]. Despite all the advantages, the main drawbacks of this kind of carbonaceous material are that it is time-consuming, and has low specific capacitance and high cost. By traditional methods, it takes at least three days to complete the so-gel process and another several days for the aging procedure. Meanwhile, the supercritical-drying technique required for the drying process is costly and energy consuming $[17,18]$. Many efforts have been tried to resolve 
these issues. For instance, Rasines and coworkers have fabricated a highly porous carbon composite composed of $\mathrm{N}$-doped aerogels and carbon black. It displays high surface area and a combined micro/mesopore structure with a desalting capacity of $7.3 \mathrm{mg} / \mathrm{g}$ [19]. Chen and coworkers have synthesized a novel porous carbon through facile hydrothermal method to prevent the unexpected re-stacking. The surface area of this 3D graphene/porous CA can achieve $2211 \mathrm{~m}^{2} \mathrm{~g}^{-1}$ and the highest capacity is up to $410 \mathrm{~F} \mathrm{~g}^{-1}$ at a current density of $0.5 \mathrm{~A} \mathrm{~g}^{-1}$ [20]. In order to shorten the synthesis procedure, some researchers have introduced microwave-assisted technology to the heating or drying process to make the fabrication much easier, faster, and cheaper [21-23].

In this report, we introduced a novel and simple method to prepare resorcinol-formaldehyde aerogel using a ring focusing single-mode microwave synthesizer. Compared with a multi-mode microwave, the single-mode microwave can make the reaction more accurate, easy to control, and with better repeatability. With the help of ring focusing and power-max technology, the sol-gel process is over 100 to 1000 times faster than traditional heating method. To optimize the specific area and pore size distribution of CAs and make it more suitable as electrode material for supercapacitor, CAs were activated, characterized and used as for supercapacitor application.

\section{Materials and Methods}

\subsection{Preparation of Carbon Aerogel}

An organic precursor was synthesized by polycondensation of resorcinol (R) and formaldehyde (F) using distilled water as solvent and sodium hydroxide as basification catalyst (C). The gel precursor solution was prepared with the molar ration of R/F and R/C fixing at 0.5 and 500 respectively and the mass fraction of the reactants (the total mass of resorcinol and formaldehyde) at $25 \mathrm{wt} \%$. Resorcinol (Aladdin, 99\%) and catalyst were first dissolved in deionized water under magnetic stirring. After that, formaldehyde (Aladdin, $37 \mathrm{wt} \%$ in water, stabilized by $10.7 \mathrm{wt} \%$ methanol) was added to the mixture solution and stirred for an hour. Subsequently, $30 \mathrm{~mL}$ of precursor solution was poured into a round-bottom flask and located in the unimode microwave cavity. The sol-gel reaction was carried out under the single-mode microwave radiation at $85^{\circ} \mathrm{C}$ and $100 \mathrm{~W}$. The excess solvent in the hydrogel was replaced by acetone for 2 days and then dried at ambient temperature to obtain resorcinol/formaldehyde (RF) organic aerogels. At last, the organic aerogels were pyrolysised in argon flow at $900{ }^{\circ} \mathrm{C}$ for $2 \mathrm{~h}$ to get the hierarchical porous carbon aerogel (CA). The synthetic process of $\mathrm{CA}$ was shown in Scheme 1.

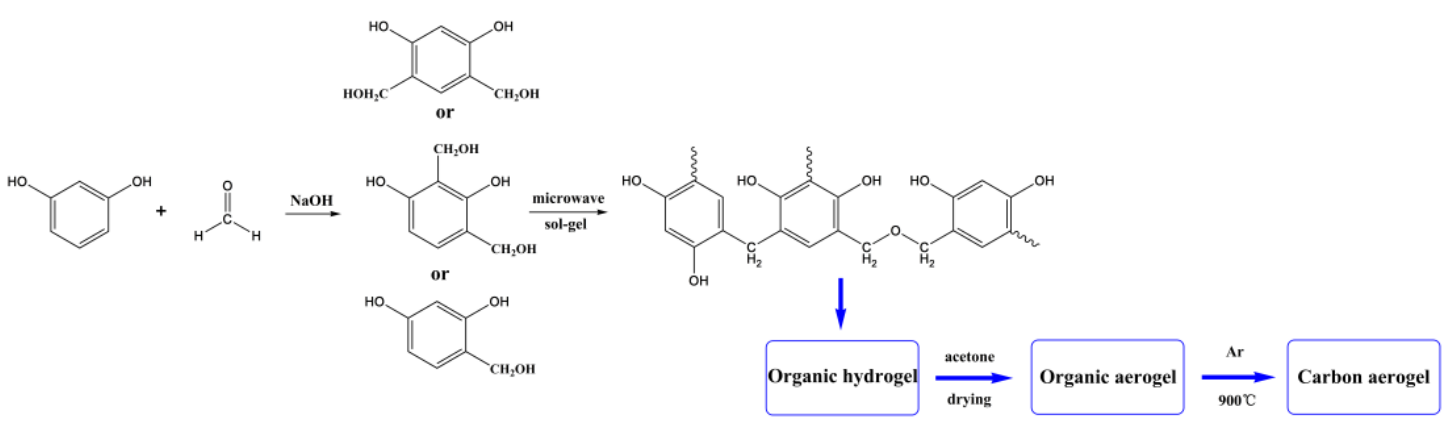

Scheme 1. Schematic diagram of synthetic process of carbon aerogel (CA).

\subsection{Activation of Carbon Aerogel}

The $\mathrm{KOH}$ activation reaction was as follows: $\mathrm{KOH}$ and $\mathrm{CA}$, with the mass ratio from 1:1 to 5:1 $\left(\mathrm{m}_{\mathrm{KOH}}: \mathrm{m}_{\mathrm{CA}}\right)$, were ground adequately in an agate mortar. The resulting mixture was activated in the nitrogen atmosphere at $800{ }^{\circ} \mathrm{C}$ for $2 \mathrm{~h}$. After cooling, the products were thoroughly washed by $1 \mathrm{M}$ $\mathrm{HCl}$ and deionized water to remove all soluble impurities and then dried at $120^{\circ} \mathrm{C}$ to obtain activated carbon aerogel. The final products were named as $\mathrm{KOH}-\mathrm{CA} 1, \mathrm{KOH}-\mathrm{CA} 2, \mathrm{KOH}-\mathrm{CA} 3, \mathrm{KOH}-\mathrm{CA} 4$, and $\mathrm{KOH}-\mathrm{CA} 5$, respectively. 


\subsection{Materials Characterization}

Field-emission scanning electron microscope (FESEM, JSM-6510, JEOL Ltd., Tokyo, Japan) and X-ray powder diffraction (Rigaku D/max 2500/PC, Rigaku Corporation, Tokyo, Japan) were used to identify the morphology and structure of the as-prepared materials. Nitrogen adsorption/desorption isotherms and textural properties were determined at $77 \mathrm{~K}$ with a Specific Surface Area and Porosity Analyzer (BELSORP-max, MicrotracBEL, Osaka, Japan).

The electrochemical performance at room temperature of the as-synthesized materials was characterized in $6 \mathrm{M} \mathrm{KOH}$ alkaline electrolyte using a CHI660E electrochemical work-station (CHI660E, Huakeputian Technology Co., Ltd., Beijing, China). The electrodes were prepared by pressing a mixture of $85 \mathrm{wt} \%$ active material, $10 \mathrm{wt} \%$ conductive carbon black and $5 \mathrm{wt} \%$ PTFE onto a nickel foam mesh current collector [24,25]. The mass of each electrode was about $5 \mathrm{mg}$. Cycle voltammetry measurements (CV) and electrochemical impedance spectroscopy (EIS, Huakeputian Technology Co., Ltd., Beijing, China) were performed in three electrodes test system while the galvanostatic charge-discharge measurement (GCD, Huakeputian Technology Co., Ltd., Beijing, China) was carried out using two-electrode cells. The specific capacitance ( $\mathrm{Csp}$ in $\mathrm{F} \mathrm{g}^{-1}$ ) can be calculated from the GCD curve according to the equation $[1,26]$ :

$$
\mathrm{Cs} p=\frac{I \Delta \mathrm{t}}{\Delta \mathrm{V} \times \mathrm{m}}
$$

where $I$ is the constant discharge current $(\mathrm{A}), \Delta \mathrm{t}$ is the discharge time (s), $\Delta \mathrm{V}$ is the working voltage window and $\mathrm{m}$ is the mass of the active material of each electrode.

\section{Results and Discussion}

\subsection{XRD Analysis of $C A$}

Figure 1 shows the XRD patterns of CA prepared with different radiation time. All the samples exhibit a board reflection at $2 \theta=23.5^{\circ}$ and $43.8^{\circ}$, which are correlated to the (002) and (100) diffraction direction of graphite. It indicates that RF organic aerogel possesses a low degree of graphitization during the carbonization $[19,27,28]$. The C-C bonds in the carbon aerogel contains both $\mathrm{sp}^{2}$ and $\mathrm{sp}^{3}$ hybrid, which results in an amorphous nature with local micro crystallites.

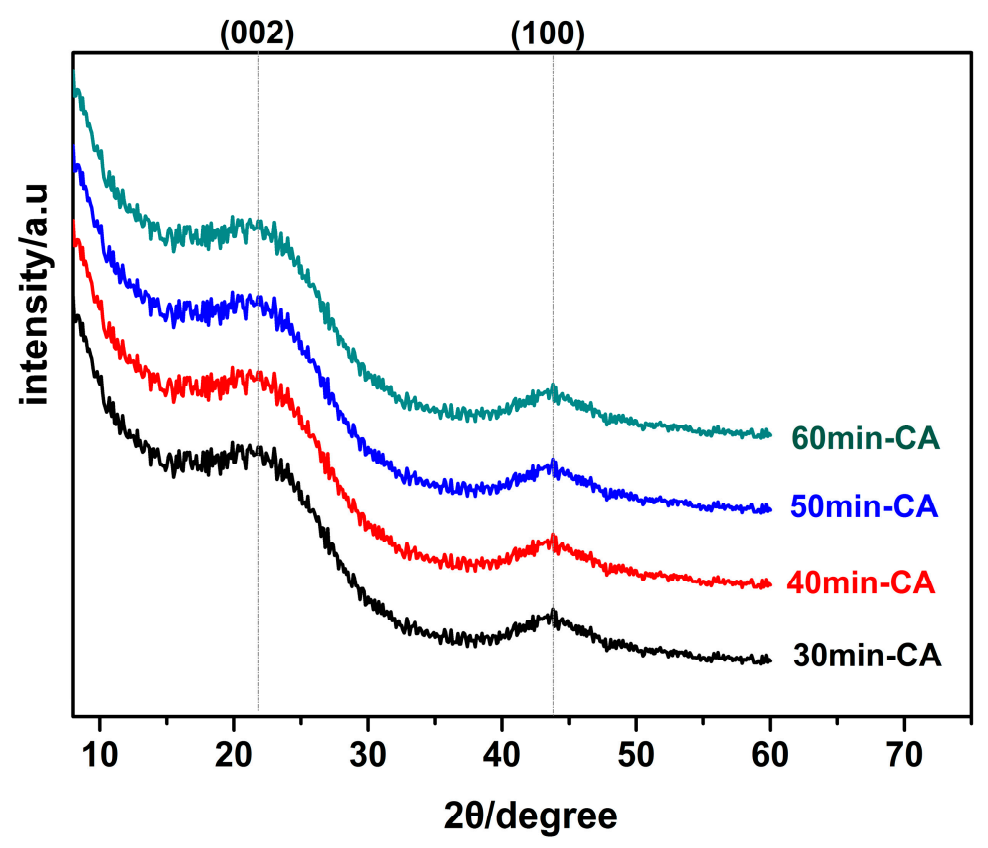

Figure 1. X-ray diffraction patterns of CAs prepared in different radiation time. 


\subsection{SEM Analysis of $C A$}

The SEM micrographs of carbon aerogels (CAs) synthesized by single-mode microwave-assisted polymerization are shown in Figure 2.
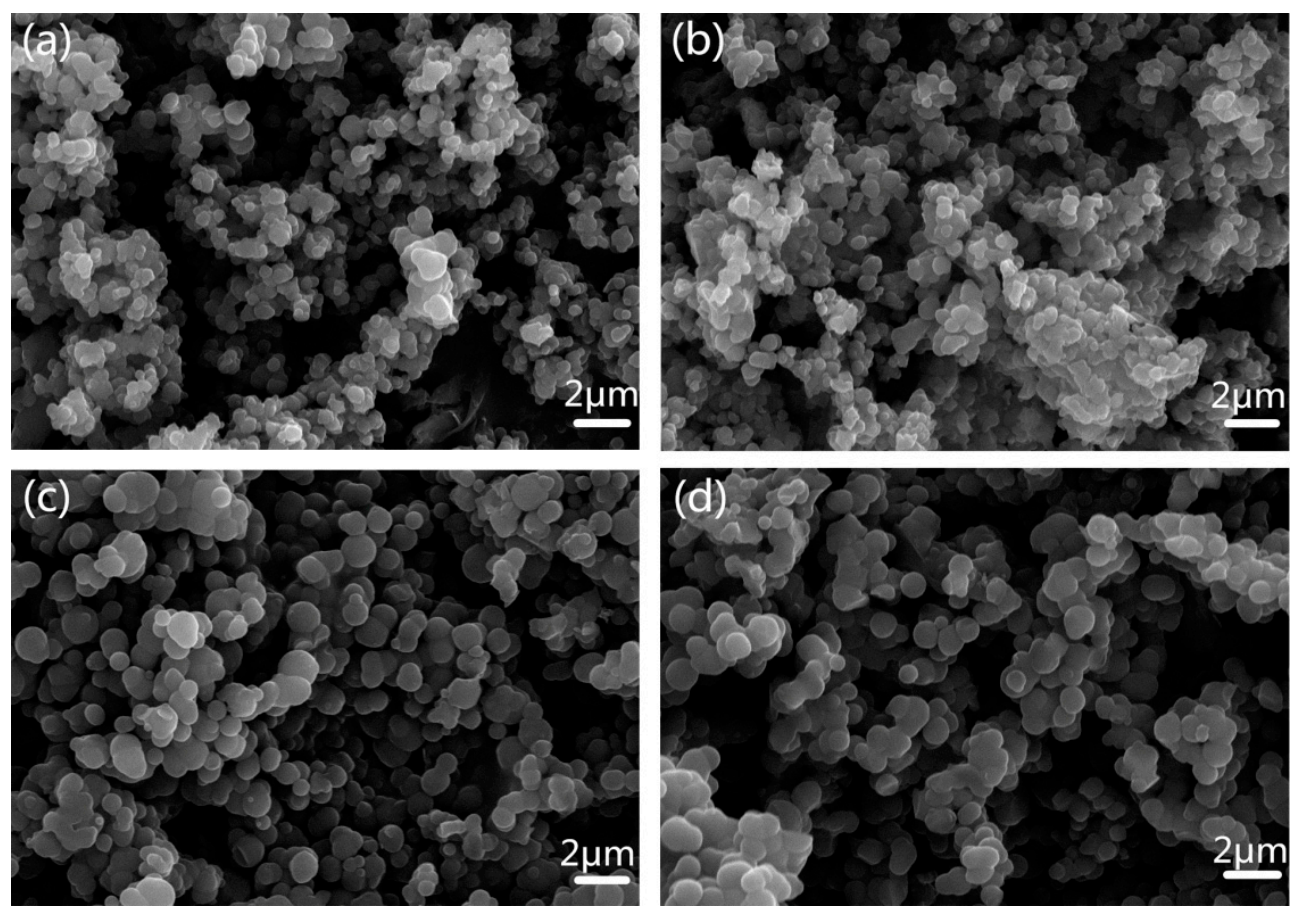

Figure 2. SEM images of (a) $30 \mathrm{~min}-\mathrm{CA}$, (b) $40 \mathrm{~min}-\mathrm{CA}$, (c) $50 \mathrm{~min}-\mathrm{CA}$, and (d) $60 \mathrm{~min}-\mathrm{CA}$.

The morphology of CAs displays a 3D-porous network structure formed by spherical nanoparticles. There is a certain gap and channel among the particles which is conducive to the rapid migration of electrolyte ion into the pores of carbon aerogel. This particular structure is suitable to store and release energy and make the CAs a good candidate for electrode materials of supercapacitor.

\subsection{Electrochemical Properties of $C A$}

To screen the optimal synthesis duration for the CAs, the electrochemical performance of the CAs prepared with different radiation durations was first assessed using a three-electrode test system with $\mathrm{Ag} / \mathrm{AgCl}$ as reference electrode and $\mathrm{Pt}$ as the counter electrode and the results are shown in Figure 3.

In Figure 3a, the as-prepared CAs display a CV curve similar to an ideal rectangular without any redox peak (at a scan rate of $5 \mathrm{mV} / \mathrm{s}$ ), which illustrates that all the samples demonstrate electric double-layer capacitance and the electrical resistance is low. Figure $3 \mathrm{~b}$ shows the charge/discharge curves of $30 \mathrm{~min}-\mathrm{CA}, 40 \mathrm{~min}-\mathrm{CA}, 50 \mathrm{~min}-\mathrm{CA}$, and $60 \mathrm{~min}-\mathrm{CA}$ at $0.5 \mathrm{~A} \mathrm{~g}^{-1}$. The GCD tests are carried out using two-electrode cell in $6 \mathrm{M} \mathrm{KOH}$. All the curves display nearly symmetrical isosceles triangles and rapid responses of current-voltage. It indicates that the electrode materials have excellent coulomb efficiency and electrochemical reversibility [1,29]. The 40 min-CA exhibits the smallest ohmic drop with the longest charge and discharge time, which can be concluded that this sample has the lowest equivalent series resistance $[20,30]$ and the highest specific capacitance. $\left(92 \mathrm{~F} \mathrm{~g}^{-1}\right.$ at $0.5 \mathrm{~A} \mathrm{~g}^{-1}$ ). Figure $3 \mathrm{c}$ shows the Nyquist plots of CAs prepared with different radiation times with the frequencies ranging from $0.1 \mathrm{~Hz}$ to $100 \mathrm{kHz}$. All plots compose of a small arc in the high frequency region and a straight line in the low frequency region. The semicircle at high frequency represents the interfacial resistance, charge transfer resistance and the conductivity of electrodes. The bias line at low frequency area reveals the diffusion resistance in the electrolyte [31-34]. The equivalent series resistance of the $40 \mathrm{~min}-\mathrm{CA}$ is about $0.47 \Omega$, which is lower than the $30 \mathrm{~min}$-CA $(0.8 \Omega), 50 \mathrm{~min}-\mathrm{CA}(0.55 \Omega)$, and $60 \mathrm{~min}-\mathrm{CA}(0.79 \Omega)$, indicating that the sample of $40 \mathrm{~min}$-CA has the lowest interfacial charge-transfer 
resistance and the highest electrical conductivity. Combined with the results of CV and GCD, we can come to the conclusion that the CA prepared by $40 \mathrm{~min}$ microwave radiation exhibits the best electrochemical performance.
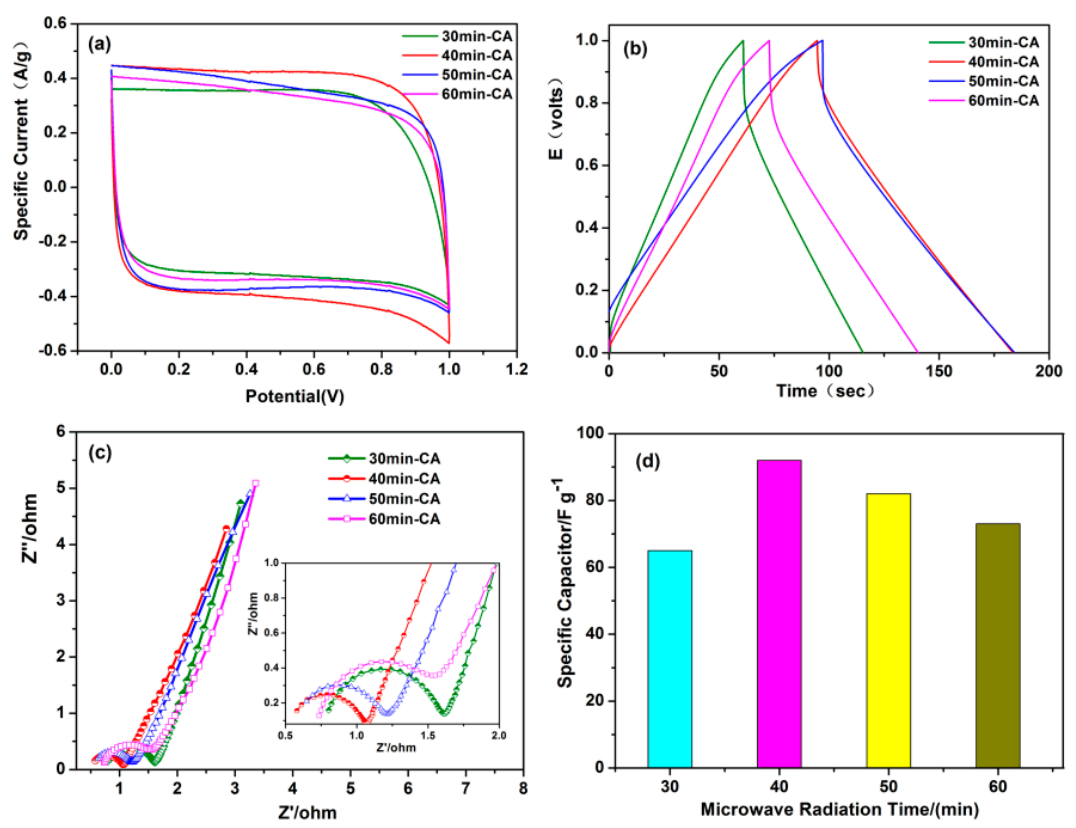

Figure 3. (a) Cyclic voltammograms of the CAs prepared in different radiation time at $5 \mathrm{mV} \mathrm{s}^{-1}$ in $6 \mathrm{M} \mathrm{KOH}$ solution. (b) Galvanostatic charge-discharge curves using a two-electrode cell at a current density of $0.5 \mathrm{~A} \mathrm{~g}^{-1}$. (c) Nyquist plot of CAs with the frequency ranging from $0.1 \mathrm{~Hz}$ to $100 \mathrm{kHz}$. (d) Specific capacitance of CAs at $0.5 \mathrm{~A} \mathrm{~g}^{-1}$.

\subsection{XRD Analysis of Activated CA}

To further optimize the pore structure and enhance the electrochemical properties of the carbon aerogel, CA was activated by various proportion of solid potassium hydroxide. XRD patterns of CAs activated by different alkali carbon ratio are shown in Figure 4.

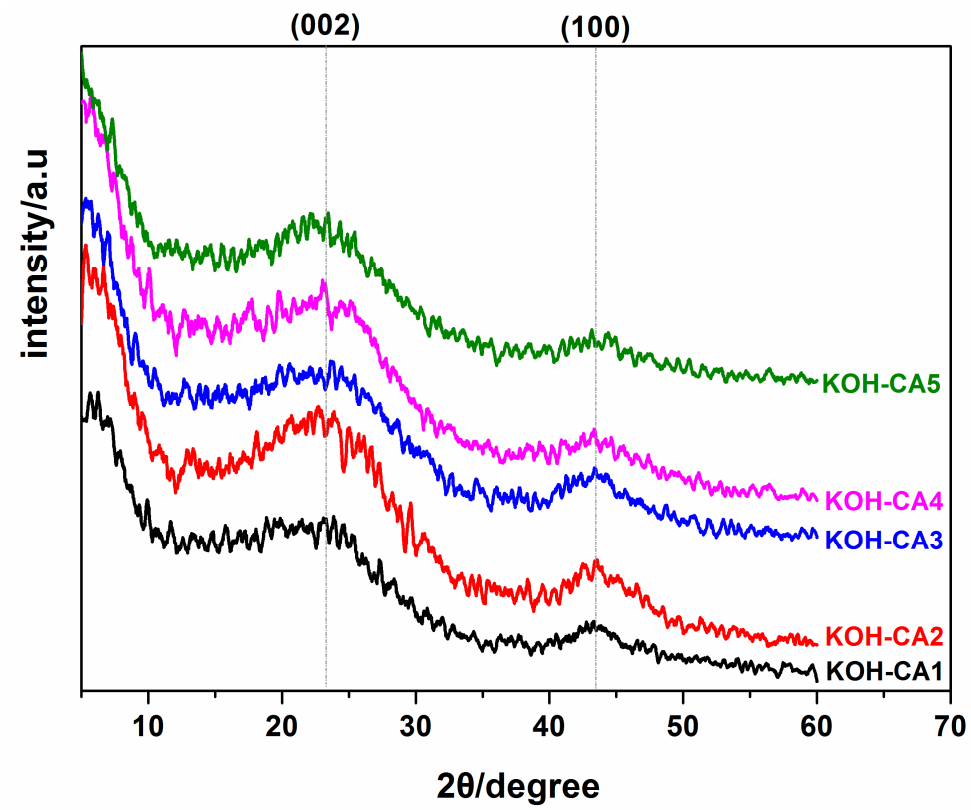

Figure 4. X-ray diffraction patterns of $\mathrm{CAs}$ activated by solid $\mathrm{KOH}$ with different mass ratio of alkali/carbon. 
With the increasing of the content of $\mathrm{KOH}$, the peak at $2 \theta=23.5^{\circ}$ remains almost identical while the reflection of $43.8^{\circ}(2 \theta)$ decreases progressively (from $\mathrm{m}_{\mathrm{KOH}}: \mathrm{m}_{\mathrm{CA}}=4: 1$ ). It is known that under high temperature, the carbon framework is etched by the redox reactions of various potassium compounds as chemical activator with carbon. Some graphite grains are consumed in these reactions, which may improve the amorphous structure of the CAs. The hierarchical porous structure of the carbon aerogel is created during this process $[35,36]$.

\subsection{SEM and BET Analysis of Activated CA}

The SEM images of CAs activated by $\mathrm{KOH}$ are shown in Figure 5. As expected, after activation by $\mathrm{KOH}$ at $800{ }^{\circ} \mathrm{C}$, diameter of the aerogel particles greatly reduces, this leads to the dramatically increase of the specific area. As a result, the contact area of carbon materials with the electrolyte ions enlarged and the active sites increased.
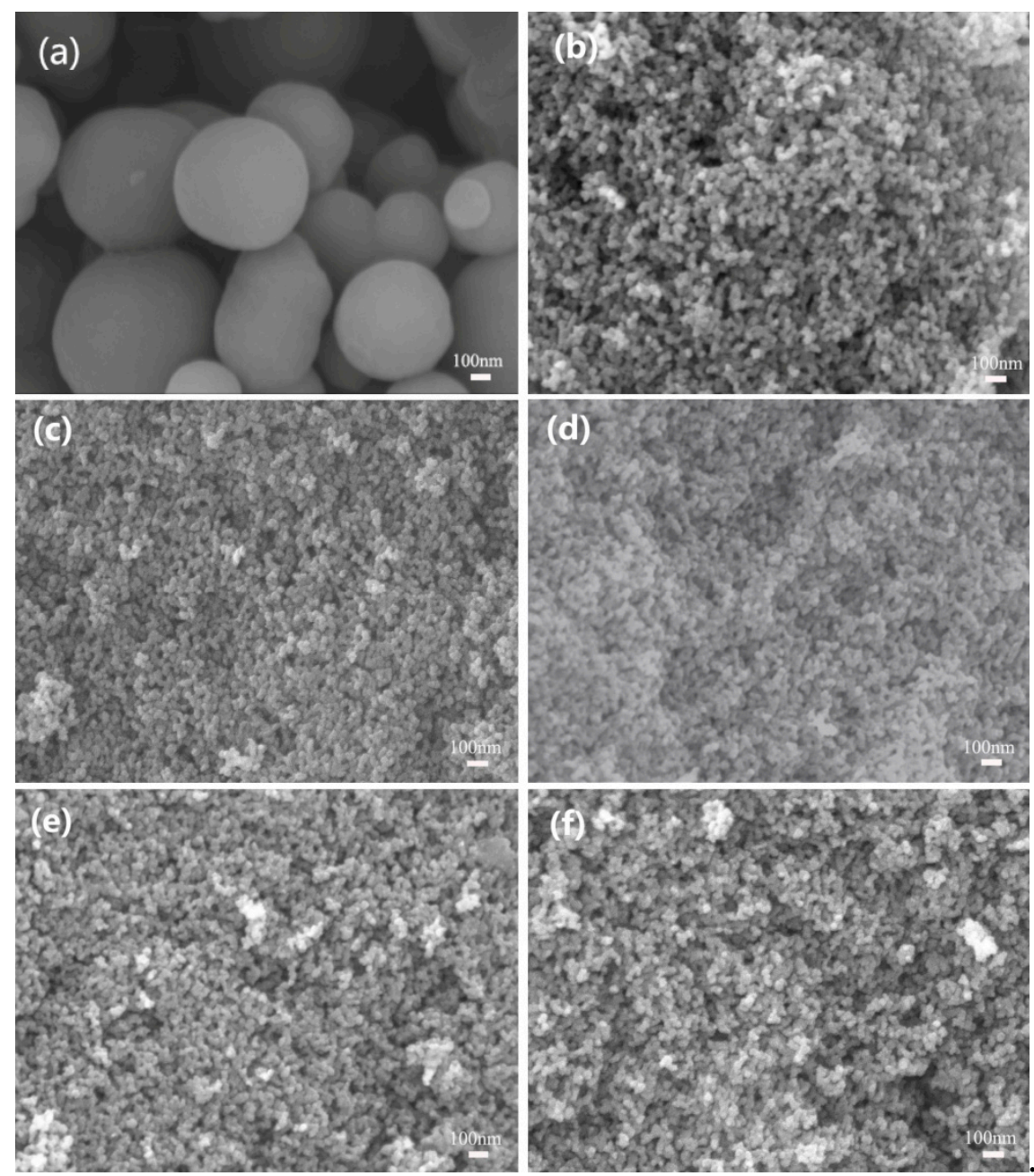

Figure 5. SEM images of (a) 40 min-CA, (b) KOH-CA1, (c) KOH-CA2, (d) KOH-CA3, (e) KOH-CA4, and (f) $\mathrm{KOH}-\mathrm{CA} 5$.

Figure 6 shows the nitrogen adsorption/desorption isotherms and pore size distribution of CA and $\mathrm{KOH}-\mathrm{CA} 3$. 

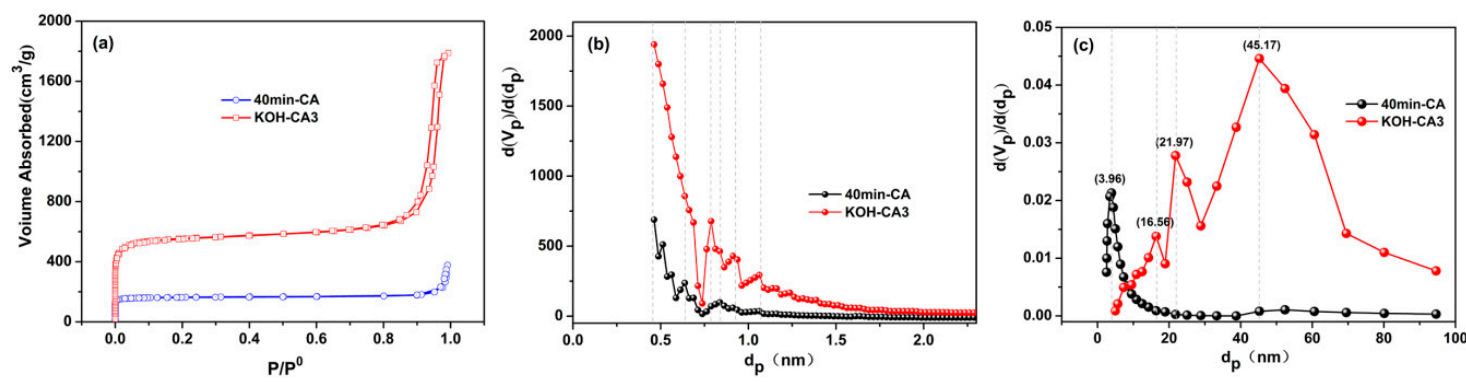

Figure 6. (a) Nitrogen adsorption/desorption isotherms of $40 \mathrm{~min}-\mathrm{CA}$ and $\mathrm{KOH}-\mathrm{CA} 3$. (b) Micropore size distributions of $40 \mathrm{~min}-\mathrm{CA}$ and $\mathrm{KOH}-\mathrm{CA} 3$ determined by $\mathrm{HK}$ (Horvath-Kawazoe) method. (c) Meso-macroporous distributions of 40 min-CA and $\mathrm{KOH}-\mathrm{CA} 3$ obtained by applying the $\mathrm{BJH}$ (Barrett-Joyner-Halenda) method.

It can be observed from Figure 6a that the CA displays a type I isotherm and that for the activated carbon aerogel ( $\mathrm{KOH}-\mathrm{CA} 3)$ is type IV. The ultra-fast adsorption increases at a low relative pressure of the two samples demonstrates a large quantity of micropores [23,37]. The obvious hysteresis loop ranging from $0.8-1.0$ of $\mathrm{KOH}-\mathrm{CA} 3$ indicates the presence of rich mesoporous [38], which can be further proved by pore size distribution in Figure $6 \mathrm{~b}$. After activation, besides the enormous increase in micropores, a moderate amount of meso/macroporous appears in $\mathrm{KOH}-\mathrm{CA} 3$, which can provide the ion transport channel and ion-buffering reservoir. The specific area and pore characteristics are listed in Table 1. Compared with the $40 \mathrm{~min}-\mathrm{CA}\left(596 \mathrm{~m}^{2} \mathrm{~g}^{-1}\right.$ and $\left.0.4025 \mathrm{~cm}^{3} \mathrm{~g}^{-1}\right)$, the specific area and pore volume of KOH-CA3 increase to $2230 \mathrm{~m}^{2} \mathrm{~g}^{-1}$ and $1.9770 \mathrm{~cm}^{3} \mathrm{~g}^{-1}$, respectively.

Table 1. Specific surface area and pore-structure characteristic of the $40 \mathrm{~min}-\mathrm{CA}$ and $\mathrm{KOH}-\mathrm{CA} 3$.

\begin{tabular}{cccc}
\hline Sample & $\begin{array}{c}\mathbf{S}_{\text {BET }} \\
\left(\mathbf{m}^{\mathbf{2}} \mathbf{g}^{-\mathbf{1}} \mathbf{)}\right.\end{array}$ & $\begin{array}{c}\mathbf{V}_{\text {total }} \\
\left(\mathbf{c m}^{\mathbf{3}} \mathbf{g}^{-\mathbf{1}} \mathbf{)}\right.\end{array}$ & $\begin{array}{c}\mathbf{d}_{\mathbf{m}} \\
(\mathbf{n m})\end{array}$ \\
\hline $40 \mathrm{~min}-\mathrm{CA}$ & 596 & 0.4025 & 2.70 \\
KOH-CA3 & 2230 & 1.9770 & 6.98 \\
\hline
\end{tabular}

\subsection{Electrochemical Properties of Activated CA}

The electrochemical performance of the activated carbon aerogel was further investigated. Figure 7a-e shows the cyclic voltammetry (CV) curves of activation carbon aerogels at different scanning rates. After activation, even at a scan rate of $100 \mathrm{mv} / \mathrm{s}$, the CV curves of these samples still reserve a near-ideal rectangular shape, indicating a typical double-layer capacitive behavior with the absence of pseudo-capacitance and a good rate capability. Figure $7 \mathrm{f}$ displays the galvanostatic charge/discharge curves of $40 \mathrm{~min}-\mathrm{CA}$ and activated CAs. The linear behavior and symmetrical curve in the potential window $(0-1 \mathrm{~V})$ are due to its high electrical conducting of its unique three dimensionally nano-framework. The IR drop can be negligible of all the activated CAs, which demonstrates the high-speed charge propagation of these as-prepared samples. As described in Table 2, the highest capacity $\left(170 \mathrm{~F} \mathrm{~g}^{-1}\right.$ at $\left.0.5 \mathrm{~A} \mathrm{~g}^{-1}\right)$ of the activated CA appears at $\mathrm{m}_{\mathrm{KOH}}: \mathrm{m}_{\mathrm{CA}}=3: 1$, which is much higher than the $40 \mathrm{~min}-\mathrm{CA}\left(92 \mathrm{~F} \mathrm{~g}^{-1}\right.$ at $\left.0.5 \mathrm{~A} \mathrm{~g}^{-1}\right)$. 

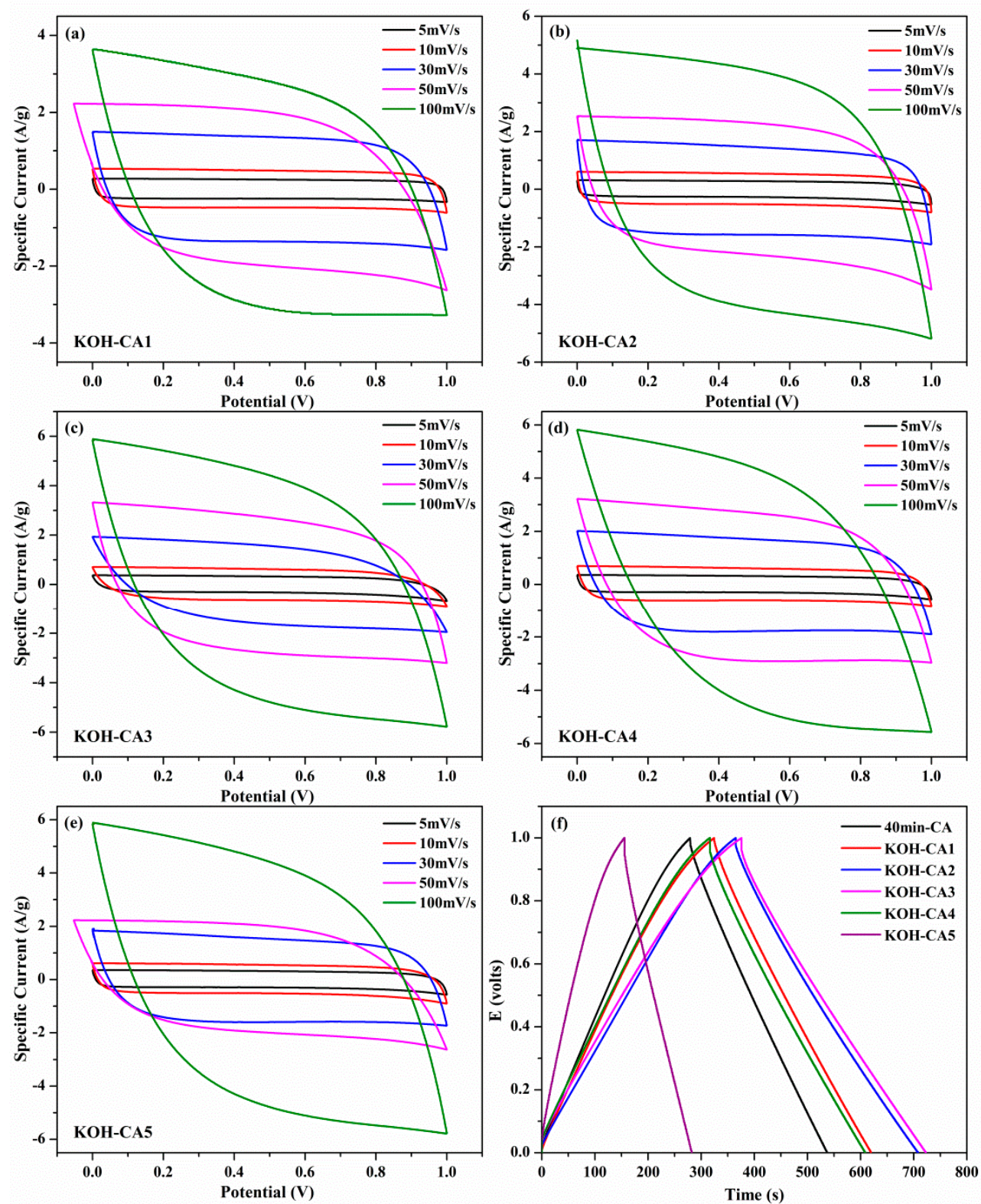

Figure 7. (a-e) Cyclic voltammograms of CAs activated by different content of solid potassium hydroxide in different scanning rates in $6 \mathrm{M} \mathrm{KOH}$ solution. (f) Galvanostatic charge-discharge curves using a two-electrode cell at a current density of $0.5 \mathrm{~A} \mathrm{~g}^{-1}$.

Table 2. Specific capacitance of CAs activated by solid KOH.

\begin{tabular}{ccc}
\hline Samples & $\mathbf{m}_{\mathbf{C A}}: \mathbf{m}_{\mathbf{K O H}}$ & Specific Capacitance $\mathbf{( F / g )}$ \\
\hline KOH-CA1 & $1: 1$ & 120 \\
KOH-CA2 & $1: 2$ & 132 \\
KOH-CA3 & $1: 3$ & 170 \\
KOH-CA4 & $1: 4$ & 146 \\
KOH-CA5 & $1: 5$ & 136 \\
\hline
\end{tabular}

After activation, the equivalent series resistance (ESR) of the $\mathrm{KOH}-\mathrm{CA} 3$ reduces to only $0.32 \Omega$ (in Figure 8). The cycling stability test of the $40 \mathrm{~min}-\mathrm{CA}$ and $\mathrm{KOH}-\mathrm{CA} 3$ are shown in Figure 9. 


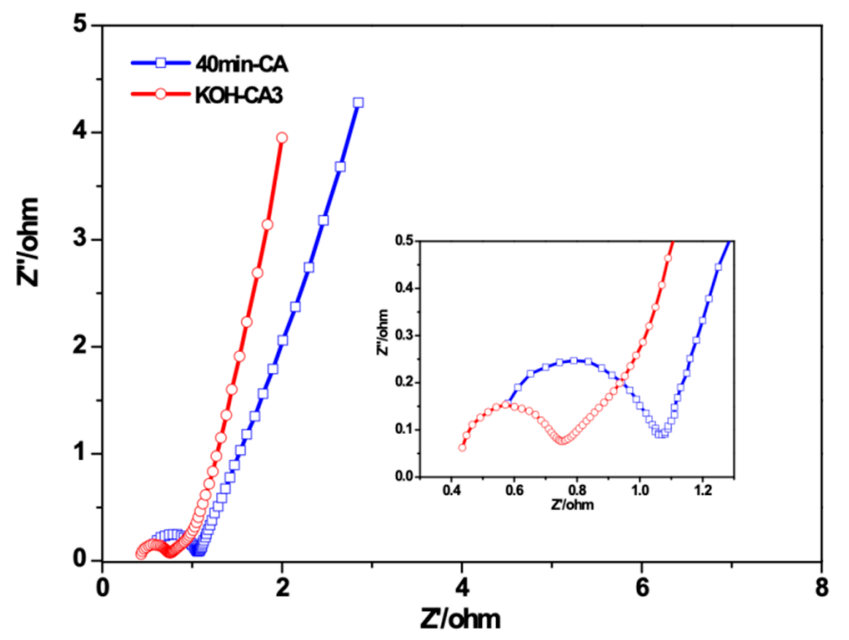

Figure 8. Nyquist plot of $\mathrm{CAs}$ activated by solid $\mathrm{KOH}$ with the frequency ranging from $0.1 \mathrm{~Hz}$ to $100 \mathrm{kHz}$.

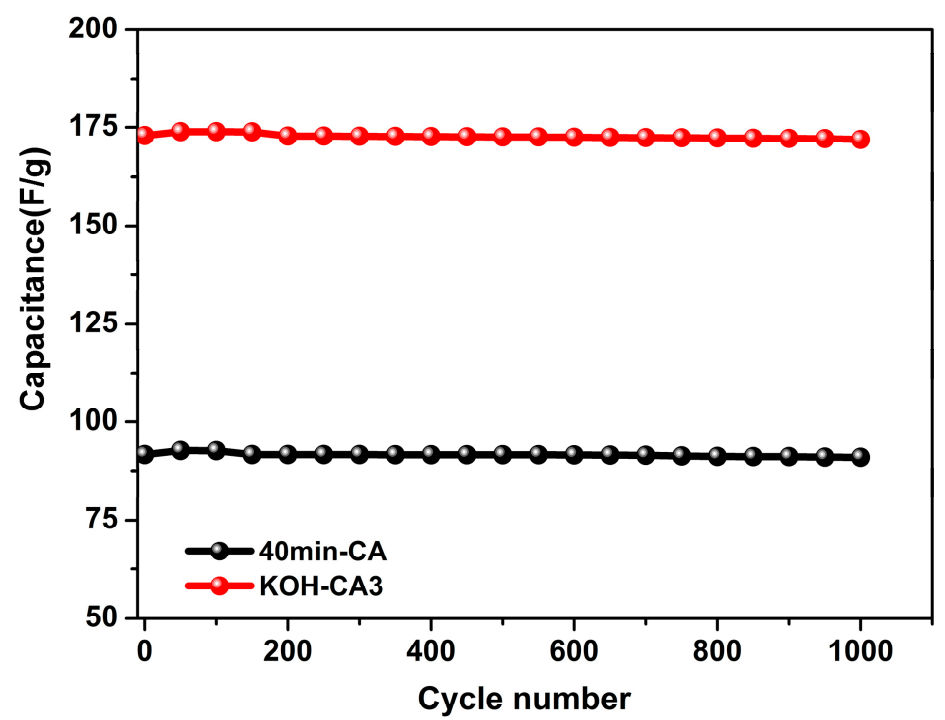

Figure 9. Cycling stability of $40 \mathrm{~min}-\mathrm{CA}$ and $\mathrm{KOH}-\mathrm{CA} 3$ electrodes measured at $0.5 \mathrm{~A}^{-1}$.

After 1000 cycles, no noticeable decrease of the specific capacitance can be seen, indicating that activation does not affect the stability of the carbon aerogel and both the two samples have good cycling performance.

\section{Conclusions}

In summary, carbon aerogels with hierarchical porous structure and excellent electrochemical performance have been prepared by carbonization and activation of resorcinol formaldehyde (RF) organic aerogels. The low-cost RF organic aerogels were prepared by using resorcinol and formaldehyde as precursors, sodium hydroxide as a catalyst through a single-mode microwave radiation assisted sol-gel method and ambient temperature drying. The fabrication procedure of carbon gel was much easier, faster, and cheaper due to the ring focusing and power-max technology. The resulting carbon aerogel (KOH-CA3) exhibits an outstanding specific surface area of $2230 \mathrm{~m}^{2} \mathrm{~g}^{-1}$ and possessed a quantity high fraction of micropores and a moderate amount of mesoporous. The specific capacitance tested in two-electrode cell and calculated from galvanostatic charge/discharge curve was $170 \mathrm{~F} \mathrm{~g}^{-1}$ at $0.5 \mathrm{~A} \mathrm{~g}^{-1}$. The as-prepared CAs shows a good rate capability and ideal cycle stability in $6 \mathrm{M} \mathrm{KOH}$ electrolyte. 
Author Contributions: Conceptualization, Methodology, Writing-Original Draft Preparation, X.C.; Validation, G.T.; Data Curation, Z.D.; Resources, J.L.; Supervision, Writing-Review \& Editing, D.G.

Funding: This research was funded by the Nature Foundation of Guangdong Province of China (Grant No. 2017A030313322).

Conflicts of Interest: The authors declare no conflict of interest.

\section{References}

1. Hao, P.; Zhao, Z.; Leng, Y.; Tian, J.; Sang, Y.; Boughton, R.I.; Wong, C.P.; Liu, H.; Yang, B. Graphene-based nitrogen self-doped hierarchical porous carbon aerogels derived from chitosan for high performance supercapacitors. Nano Energy 2015, 15, 9-23. [CrossRef]

2. Yang, T.; Li, R.; Long, X.; Li, Z.; Gu, Z.; Wang, G.; Liu, J. Nitrogen and sulphur-functionalized multiple graphene aerogel for supercapacitors with excellent electrochemical performance. Electrochim. Acta 2015, $187,143-152$.

3. Xu, Y.L.; Ren, B.; Wang, S.S.; Zhang, L.H.; Liu, Z.F. Carbon aerogel-based supercapacitors modified by hummers oxidation method. J. Colloid Interface Sci. 2018, 527, 25-32. [CrossRef] [PubMed]

4. Veerasubramani, G.K.; Krishnamoorthy, K.; Pazhamalai, P.; Kim, S.J. Enhanced electrochemical performances of graphene based solid-state flexible cable type supercapacitor using redox mediated polymer gel electrolyte. Carbon 2016, 105, 638-648. [CrossRef]

5. Zhang, Q.; Han, K.; Li, S.; Li, M.; Li, J.; Ren, K. Synthesis of garlic skin-derived 3D hierarchical porous carbon for high-performance supercapacitors. Nanoscale 2018, 5, 2427-2437. [CrossRef] [PubMed]

6. Yang, W.; Hou, L.Q.; Xu, X.W.; Li, Z.H.; Ma, X.L.; Yang, F.; Li, Y.F. Carbon nitride template-directed fabrication of nitrogen-rich porous graphene-like carbon for high performance supercapacitors. Carbon 2018, 130, 325-332. [CrossRef]

7. Park, M.S.; Lim, Y.G.; Park, J.W.; Kim, J.S.; Lee, J.W.; Kim, J.H.; Dou, S.X.; Kim, Y.J. $\mathrm{Li}_{2} \mathrm{RuO}_{3}$ as an Additive for High-Energy Lithium-Ion Capacitors. J. Phys. Chem. C 2013, 117, 11471-11478. [CrossRef]

8. Dutta, S. Hierarchically porous carbon derived from polymers and biomass: Effect of interconnected pores on energy applications. Energy Environ. Sci. 2014, 7, 3574-3592. [CrossRef]

9. Borchardt, L.; Oschatz, M.; Kaskel, S. Tailoring porosity in carbon materials for supercapacitor applications. Mater. Horiz. 2014, 1, 157-168. [CrossRef]

10. You, B.; Jiang, J.; Fan, S. Three-dimensional hierarchically porous all-carbon foams for supercapacitor. ACS Appl. Mater. Interfaces 2014, 6, 15302-15308. [CrossRef] [PubMed]

11. Sui, Z.Y. High surface area porous carbons produced by steam activation of graphene aerogels. J. Mater. Chem. A 2014, 2, 9891-9898. [CrossRef]

12. Jiang, H.; Lee, P.S.; Li, C. 3D carbon based nanostructures for advanced supercapacitors. Energy Environ. Sci. 2012, 6, 41-53. [CrossRef]

13. Calvo, E.G.; Ferrera-Lorenzo, N.; Menéndez, J.A.; Arenillas, A. Microwave synthesis of micro-mesoporous activated carbon xerogels for high performance supercapacitors. Microporous Mesoporous Mater. 2013, 168, 206-212. [CrossRef]

14. Simon, P.; Gogotsi, Y.; Dunn, B. Where do batteries end and supercapacitors begin. Science 2014, 343, 1210-1211. [CrossRef] [PubMed]

15. Zubizarreta, L.; Arenillas, A.; Menéndez, J.A.; Pis, J.J.; Pirard, J.P.; Job, N. Microwave drying as an effective method to obtain porous carbon xerogels. J. Non-Cryst. Solids 2008, 354, 4024-4026. [CrossRef]

16. Zubizarreta, L.; Arenillas, A.; Domínguez, A.; Menéndez, J.A.; Pis, J.J. Development of microporous carbon xerogels by controlling synthesis conditions. J. Non-Cryst. Solids 2008, 354, 817-825. [CrossRef]

17. Calvo, E.G.; Ania, C.O.; Zubizarreta, L.; Menéndez, J.A.; Arenillas, A. Exploring New Routes in the Synthesis of Carbon Xerogels for Their Application in Electric Double-Layer Capacitors. Energy Fuels 2010, 24, 3334-3339. [CrossRef]

18. Halama, A.; Szubzda, B.; Pasciak, G. Carbon aerogels as electrode material for electrical double layer supercapacitors-synthesis and properties. Electrochim. Acta 2010, 55, 7501-7505. [CrossRef]

19. Rasines, G.; Lavela, P.; Macías, C.; Zafra, M.C.; Tirado, J.L.; Ania, C.O. On the use of carbon black loaded nitrogen-doped carbon aerogel for the electrosorption of sodium chloride from saline water. Electrochim. Acta 2015, 170, 154-163. [CrossRef] 
20. Chen, T.T.; Song, W.L.; Fan, L.Z. Engineering graphene aerogels with porous carbon of large surface area for flexible all-solid-state supercapacitors. Electrochim. Acta 2015, 165, 92-97. [CrossRef]

21. Menéndez, J.A.; Arenillas, A.; Fidalgo, B.; Fernández, Y.; Zubizarreta, L.; Calvo, E.G.; Bermúdez, J.M. Microwave heating processes involving carbon materials. Fuel Process. Technol. 2010, 91, 1-8. [CrossRef]

22. Calvo, E.G.; Juárez-Pérez, E.J.; Menéndez, J.A.; Arenillas, A. Fast microwave-assisted synthesis of tailored mesoporous carbon xerogels. J. Colloid Interface Sci. 2011, 357, 541-547. [CrossRef] [PubMed]

23. Yong, L.; Pan, L.; Chen, T.; Xu, X.; Lu, T.; Zhuo, S.; Chua, D.H.C. Porous carbon spheres via microwave-assisted synthesis for capacitive deionization. Electrochim. Acta 2015, 151, 489-496.

24. Liu, C.; Yu, Z.; Neff, D.; Zhamu, A.; Jang, B.Z. Graphene-Based Supercapacitor with an Ultrahigh Energy Density. Nano Lett. 2010, 10, 4863-4868. [CrossRef] [PubMed]

25. Demarconnay, L.; Calvo, E.G.; Timperman, L.; Anouti, M.; Lemordant, D.; Raymundo-Piñero, E.; Arenillas, A.; Menéndez, J.A.; Béguin, F. Optimizing the performance of supercapacitors based on carbon electrodes and protic ionic liquids as electrolytes. Electrochim. Acta 2013, 108, 361-368. [CrossRef]

26. Li, C.; Yang, X.; Zhang, G. Mesopore-dominant activated carbon aerogels with High surface area for Electric double-layer capacitor application. Mater. Lett. 2015, 161, 538-541. [CrossRef]

27. Lin, Y.H.; Wei, T.Y.; Chien, H.C.; Lu, S.Y. Manganese Oxide/Carbon Aerogel Composite: An Outstanding Supercapacitor Electrode Material. Adv. Energy Mater. 2011, 1, 901-907. [CrossRef]

28. Zhuo, H.; Hu, Y.; Tong, X.; Zhong, L.; Peng, X.; Sun, R. Sustainable hierarchical porous carbon aerogel from cellulose for high-performance supercapacitor and $\mathrm{CO}_{2}$ capture. Ind. Crops Prod. 2016, 87, 229-235. [CrossRef]

29. Zhang, H. A high-performance supercapacitor based on a polythiophene/multiwalled carbon nanotube composite by electropolymerization in an ionic liquid microemulsion. J. Mater. Chem. A 2014, 2, 17024-17030. [CrossRef]

30. Wang, C.C.; Chen, H.C.; Lu, S.Y. Manganese oxide/graphene aerogel composites as an outstanding supercapacitor electrode material. Chemistry 2014, 20, 517-523. [CrossRef] [PubMed]

31. Yan, C.; Zou, L.; Short, R. Polyaniline-modified activated carbon electrodes for capacitive deionisation. Desalination 2014, 333, 101-106. [CrossRef]

32. Yang, C.; Chen, C.; Pan, Y.; Li, S.; Wang, F.; Li, J.; Li, N.; Li, X.; Zhang, Y.; Li, D. Flexible highly specific capacitance aerogel electrodes based on cellulose nanofibers, carbon nanotubes and polyaniline. Electrochim. Acta 2015, 182, 264-271. [CrossRef]

33. Wang, G.; Ling, Z.; Li, C.; Dong, Q.; Qian, B.; Qiu, J. Ionic liquid as template to synthesize carbon xerogels by coupling with $\mathrm{KOH}$ activation for supercapacitors. Electrochem. Commun. 2013, 31, 31-34. [CrossRef]

34. Cheng, Q.; Tang, J.; Ma, J.; Zhang, H.; Shinya, N.; Qin, L.C. Graphene and carbon nanotube composite electrodes for supercapacitors with ultra-high energy density. Phys. Chem. Chem. Phys. 2011, 13, 17615-17624. [CrossRef] [PubMed]

35. Wang, J. KOH activation of carbon-based materials for energy storage. J. Mater. Chem. 2012, 22, 23710-23725. [CrossRef]

36. Xu, B.; Chen, Y.; Gang, W.; Cao, G.; Hao, Z.; Yang, Y. Activated carbon with high capacitance prepared by $\mathrm{NaOH}$ activation for supercapacitors. Mater. Chem. Phys. 2010, 124, 504-509. [CrossRef]

37. Kim, N.D.; Kim, W.; Ji, B.J.; Oh, S.; Kim, P.; Kim, Y.; Yi, J. Electrochemical capacitor performance of N-doped mesoporous carbons prepared by ammoxidation. J. Power Sources 2008, 180, 671-675. [CrossRef]

38. Park, K.H.; Kwak, D.H. Electrosorption and electrochemical properties of activated-carbon sheet electrode for capacitive deionization. J. Electroanal. Chem. 2014, 732, 66-73. [CrossRef]

(C) 2019 by the authors. Licensee MDPI, Basel, Switzerland. This article is an open access article distributed under the terms and conditions of the Creative Commons Attribution (CC BY) license (http://creativecommons.org/licenses/by/4.0/). 